\title{
Return to work rates and activity profiles: are there differences between those receiving C-ADR and ACDF?
}

Authors Vincent C Traynelis', Barbara C Leigh ${ }^{2}$, Andrea C Skelly ${ }^{2}$

Institutions 'Department of Neurosurgery, Rush University Medical Center, Chicago, IL, USA

${ }^{2}$ Spectrum Research Inc, Tacoma, WA, USA

\section{ABSTRACT}

Study design: Comparative effectiveness review.

Study rationale: The ability of a patient to return to work and the speed with which this occurs are important outcome metrics for the assessment of patients undergoing spinal surgery.

Clinical questions: In patients with degenerative disease of the cervical spine, does cervical artificial disc replacement (C-ADR) lead to better work-related outcomes than fusion? Does return to work after surgery differ based on gender, age, smoking, litigation status, workers' compensation status, or other sociodemographic factors?

Methods: A systematic search and review of the English-language literature was undertaken to identify studies published through October 2, 2011. PubMed, Cochrane, National Guideline Clearinghouse Databases, and bibliographies of key articles were searched. Two individuals independently reviewed articles based on inclusion and exclusion criteria, which were set a priori. Each article was evaluated using a predefined quality-rating scheme.

Results: For follow-up periods of more than 6 months, there was no significant difference in work status between disc replacement and fusion patients; however, C-ADR patients began working sooner after surgery. Statistical significance for earlier return was not reached in all studies.

Conclusions: Most patients undergoing cervical decompression and fusion or C-ADR return to work. The rates are equivalent at 6 months but patients treated with C-ADR resumed work sooner. 


\section{STUDY RATIONALE AND CONTEXT}

Patients with cervical radiculopathy due to single-level degenerative disc disease who fail to improve with nonoperative therapy are candidates for anterior decompression and reconstruction with either an arthrodesis or arthroplasty. Both procedures require minimal hospitalization and are highly effective in relieving pain and improving neurological function. These patients are usually in the middle of their working careers. The ability to return to work and the speed with which this occurs are important to the individual being treated and also to society. Arthrodesis and arthroplasty differ in that one treatment eliminates motion at a cervical spinal segment while the other preserves it. This fundamental difference may impact postoperative function in terms of activity level, which ultimately could facilitate or hinder the ability to return to work.

\section{CLINICAL QUESTIONS}

1. In patients with degenerative disease of the cervical spine, does cervical artificial disc replacement lead to better work-related outcomes than fusion?

2. Does return to work after surgery differ based on gender, age, smoking, litigation status, workers' compensation status, or other sociodemographic factors?

Fig 1 Results of literature search.

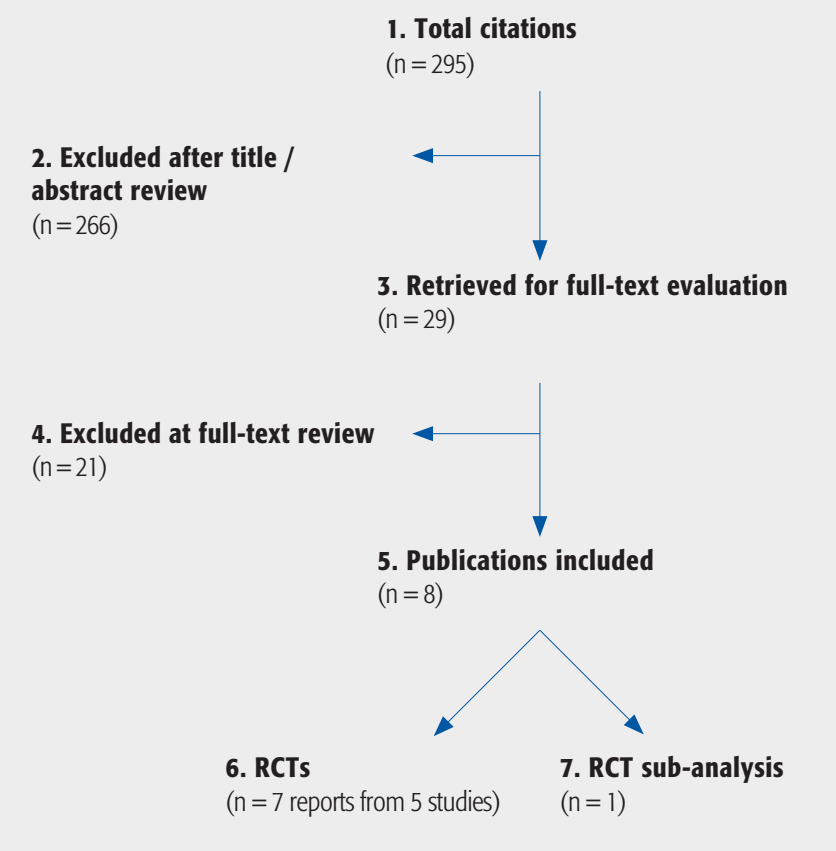

\section{METHODS}

Study design: Systematic review.

Search: PubMed, bibliographies of key articles.

Dates searched: January 2000-October 2, 2011.

Inclusion criteria: Studies (CoE I-II) directly comparing cervical artificial disc replacement (C-ADR) with discectomy and fusion (anterior cervical discectomy and fusion $[\mathrm{ACDF}]$ ) in patients with degenerative cervical disc disease; US Food and Drug Administration (FDA) approved or unapproved devices in phase III trials with $\geq 1$ year of follow-up data in a peer-reviewed journal; subanalysis data from FDA investigational device exemption (IDE) trials.

Exclusion criteria: Studies in patients with disc replacement or fusion in the thoracic or lumbar spine.

Outcomes: Proportion of patients working at follow-up; time to return to work following surgery.

Analysis: Proportion of patients working and mean or median number of days until return to work were abstracted from the reports as available. Pooling of data was not done due to concerns regarding heterogeneity and the lack of well-defined measures of return to work.

Additional methodological and technical details are provided in the Web Appendix at www.aospine.org/ebsj

\section{RESULTS}

We identified eight reports that met our inclusion criteria, which included information on return to work. From a total of 295 citations retrieved, 46 reports were selected for full-text review (Fig 1). Of these, eight met the inclusion criteria, four of which described the same study at different follow-up points (Table 1). Seven article representing four randomized controlled trials (CoE II) and four artificial discs are critically summarized: Bryan ${ }^{\circledR}$ Cervical Disc: US $[1,2]$ and China [3], Prestige ${ }^{\circledR}$ ST $[4,5]$, ProDisc-C [6], and KineflexIC [7]. In addition, we summarized a secondary analysis of data from the U. Bryan ${ }^{\circledR}$ and Prestige ${ }^{\circledR}$ RCTs that focused on a subset of patients who were covered by workers' compensation [8]. 
Table 1 Characteristics of studies comparing cervical artificial disc replacement (C-ADR) with anterior cervical discectomy and fusion (ACDF).

\begin{tabular}{|c|c|c|c|c|c|c|}
\hline Author (year) & $\begin{array}{l}\text { Study } \\
\text { design }\end{array}$ & Population & Condition & Interventions & Follow-up & $\begin{array}{l}\text { Class of } \\
\text { evidence }\end{array}$ \\
\hline $\begin{array}{l}\text { Heller et al [1] (2009) } \\
\text { Sasso et al [2] (2011) }\end{array}$ & $\begin{array}{l}\text { Multisite } \\
\text { RCT }\end{array}$ & $\begin{array}{l}\mathrm{N}=463 \\
\text { Mean age: } 44.6 \mathrm{y} \\
48 \% \text { male }\end{array}$ & $\begin{array}{l}\text { Symptomatic single-level } \\
\text { cervical disease secondary } \\
\text { to disc herniation or focal } \\
\text { osteophytes }\end{array}$ & $\begin{array}{l}\text { Bryan Cervical Disc System prosthesis } \\
\text { Fusion with anterior cervical plate } \\
\text { stabilization and bone allograft }\end{array}$ & $\begin{array}{l}24 \text { mo: } 91.6 \% \\
48 \text { mo: } 75 \%\end{array}$ & $\|$ \\
\hline $\begin{array}{l}\text { Mummaneni et al [5] } \\
\text { (2007) } \\
\text { Burkus et al [4] (2010) }\end{array}$ & $\begin{array}{l}\text { Multisite } \\
\text { RCT }\end{array}$ & $\begin{array}{l}\mathrm{N}=541 \\
\text { Mean age: } 43.6 \mathrm{y} \\
46.2 \% \text { male }\end{array}$ & $\begin{array}{l}\text { Symptomatic single-level } \\
\text { cervical degenerative disc } \\
\text { disease (C3-C7) }\end{array}$ & $\begin{array}{l}\text { Prestige ST Cervical Disc System prosthesis } \\
\text { Interbody fusion with cortical ring allograft } \\
\text { spacers and Atlantis Cervical Plate System }\end{array}$ & $\begin{array}{l}24 \text { mo: } 77.8 \% \\
60 \text { mo: } 50.1 \%\end{array}$ & $\|$ \\
\hline $\begin{array}{l}\text { Murrey et al [6] } \\
(2009)\end{array}$ & $\begin{array}{l}\text { Multisite } \\
\text { RCT }\end{array}$ & $\begin{array}{l}\mathrm{N}=209 \\
\text { Mean age: } 42.1 \text { y } \\
45 \% \text { male }\end{array}$ & $\begin{array}{l}\text { Symptomatic single-level } \\
\text { cervical disc disease } \\
\text { (C3-C7) }\end{array}$ & $\begin{array}{l}\text { ProDisc-C Cervical Disc System prosthesis } \\
\text { Fusion with cortical ring allograft spacers } \\
\text { and Cervical Plate System }\end{array}$ & 24 mo: $97 \%$ & $\|$ \\
\hline Cheng et al [3] (2011) & $\begin{array}{l}\text { Single-site } \\
\text { RCT }\end{array}$ & $\begin{array}{l}\mathrm{N}=83 \\
\text { Mean age: } 47.5 \mathrm{y} \\
53 \% \text { male }\end{array}$ & $\begin{array}{l}\text { Intractable cervical } \\
\text { myelopathy attributable to } \\
\text { disc herniation or stenosis at } \\
\text { one, two, or three levels } \\
\text { from C3-C4 to C6-C7 }\end{array}$ & $\begin{array}{l}\text { Bryan Cervical Disc System prosthesis } \\
\text { Fusion with iliac crest autograft and plate }\end{array}$ & 36 mo: $97.6 \%$ & $\|$ \\
\hline Coric et al [7] (2011) & $\begin{array}{l}\text { Multisite } \\
\text { RCT }\end{array}$ & $\begin{array}{l}\mathrm{N}=269 \\
\text { Mean age: } 43.8 \mathrm{y} \\
40.9 \% \text { male }\end{array}$ & $\begin{array}{l}\text { Symptomatic single-level } \\
\text { cervical degenerative disc } \\
\text { disease }(\mathrm{C} 3-\mathrm{C} 7)\end{array}$ & $\begin{array}{l}\text { Kineflex|C Cervical Disc System prosthesis } \\
\text { Fusion with cortical ring allograft spacers } \\
\text { and Cervical Plate System }\end{array}$ & $\begin{array}{l}24 \mathrm{mo}(\mathrm{min}): \\
87 \%\end{array}$ & $\|$ \\
\hline $\begin{array}{l}\text { Steinmetz et al [11] } \\
\text { (2011) }\end{array}$ & $\begin{array}{l}\text { Sub- } \\
\text { analysis of } \\
\text { RCT data }\end{array}$ & $\begin{array}{l}\mathrm{n}=93 \\
\text { Mean age: NR } \\
\% \text { male }\end{array}$ & $\begin{array}{l}\text { Worker's compensation } \\
\text { participants from FDA IDE } \\
\text { trials of Bryan and Prestige } \\
\text { discs }\end{array}$ & $\begin{array}{l}\text { Bryan Trial }(n=26) \\
\text { Bryan } n=15 \\
\text { ACDF } n=11 \\
\text { Prestige Trial }(n=67) \\
\text { Prestige } n=32 \\
\text { ACDF } n=35\end{array}$ & $24 \mathrm{mo}$ & $\mathrm{N} / \mathrm{A}$ \\
\hline
\end{tabular}

*RCT indicates randomized controlled trial; NR, not reported; and N/A, not applicable.

Table 2 Percentage of patients working at follow-up.*

\begin{tabular}{|c|c|c|c|c|c|c|c|c|c|c|c|c|c|c|c|c|c|}
\hline \multirow[t]{2}{*}{$\mathbf{N}$} & & \multicolumn{2}{|c|}{ Preop } & \multicolumn{2}{|c|}{6 wk } & \multicolumn{2}{|c|}{$3 \mathrm{mo}$} & \multicolumn{2}{|c|}{$6 \mathrm{mo}$} & \multicolumn{2}{|c|}{$12 \mathrm{mo}$} & \multicolumn{2}{|c|}{$24 \mathrm{mo}$} & \multicolumn{2}{|c|}{$48 \mathrm{mo}$} & \multicolumn{2}{|c|}{$60 \mathrm{mo}$} \\
\hline & & 产 & 㞫 & 啚 & 㞫 & 产 & 㞫 & 产 & 㞫 & 路 & 㞫 & 善 & 岂 & 踣 & 㞫 & 养 & 岂 \\
\hline $\begin{array}{l}\text { Bryan US } \\
\text { Heller et al [1], } 24 \mathrm{mo} \\
\text { Sasso et al [2], } 48 \mathrm{mo}\end{array}$ & 463 & 64.5 & 65 & 49.2 & $39.4^{\dagger}$ & 73.1 & 66.2 & 77.0 & 74.1 & 74.4 & 74.5 & $76.8 \%$ & $73.6 \%$ & 74.7 & 67.9 & NR & NR \\
\hline $\begin{array}{l}\text { Prestige } \\
\text { Mummaneni et al } \\
{[5], 24 \text { mo }} \\
\text { Burkus et al [4], } 60 \\
\text { mo }\end{array}$ & 541 & 66 & 63 & NR & NR & NR & NR & NR & NR & NR & NR & 75.4 & 74.7 & NR & NR & 76.3 & 72.6 \\
\hline $\begin{array}{l}\text { Prodisc } \\
\text { Murrey et al [6] }\end{array}$ & 209 & 82.5 & 84.9 & NR & NR & NR & NR & NR & NR & NR & NR & 82.8 & 80.0 & NR & NR & NR & NR \\
\hline \multicolumn{18}{|c|}{ Secondary analysis of workers' compensation patients in Bryan and Prestige trials } \\
\hline $\begin{array}{l}\text { Prestige and Bryan } \\
\text { Steinmetz et al [11] }\end{array}$ & 93 & 36.2 & 32.6 & 17.8 & $2.2^{\dagger}$ & 45.7 & $21.7^{\dagger}$ & 54.5 & 42.2 & 61.9 & 50 & 63.2 & 52.8 & NR & NR & NR & NR \\
\hline
\end{tabular}

*C-ADR indicates total disc replacement; ACDF, anterior cervical discectomy and fusion; WC, workers' compensation; and NR, not reported.

$+p<.05$.

$\ddagger P<.10$. 
Further details on the class of evidence rating and additional data for these studies can be found in the Web Appendix at www.aospine.org/ebsj.

\section{Percentage of patients working at follow-up (Tables 2-3)}

- In two studies [2,4], the overall proportion of patients who were working increased postoperatively approximately $10 \%-12 \%$ (from $65 \%$ preoperatively to $75 \%$ at 24 months). Larger improvements were evident among workers' compensation patients (from 36\%-63\%) [8], and a third study [6] reported no preoperative or postoperative differences in work status.

- At 24 months postoperatively, there was no significant difference in work status between disc replacement and fusion patients across three trials.

- Work status less than 24 months after surgery was reported in only one study [2], and suggested that disc replacement patients were more likely than fusion patients to be working 6 weeks after surgery. This difference was more pronounced in workers' compensation patients [8].

- Patients covered by workers' compensation appeared to be less likely to be working at all time points; however, no direct statistical comparisons of these patients-topatients with other insurance were reported.

\section{Time returning to work postoperatively (Fig 2)}

- Patients who received disc replacement began working sooner after surgery than patients who received fusion with statistical significance reported in two studies.

- After controlling for gender, study, and preoperative work status, the difference between treatments for median time to work return among worker's compensation participants did not reach statistical significance. Among patients who were covered by workers' compensation, those who were working at the time of surgery returned to work sooner than did patients in the full sample of the worker's compensation patients. No direct comparison of workmen's compensation patients-to-other patients was reported.

\section{Differential effects of C-ADR/ACDF on return to work}

- No studies examined differential work-related outcomes by gender, smoking status, litigation, or any characteristic other than workers' compensation.

- No direct comparisons of worker's compensation patients-to-patients with other insurance were possible. The pattern of findings for workers' compensation patients, however, was similar to that of patients in general: earlier return to work with disc replacement compared with fusion and no significant group differences in work status after 6 months.

\section{Activity levels}

- One study [7] reported that the proportion of patients who rated their activity level as "moderately active or active" was equivalent in C-ADR and ACDF groups. No definitions of activity level were provided.

Fig 2 Median number of days from surgery to return to work. C-ADR indicates total disc replacement; ACDF, anterior cervical discectomy and fusion.

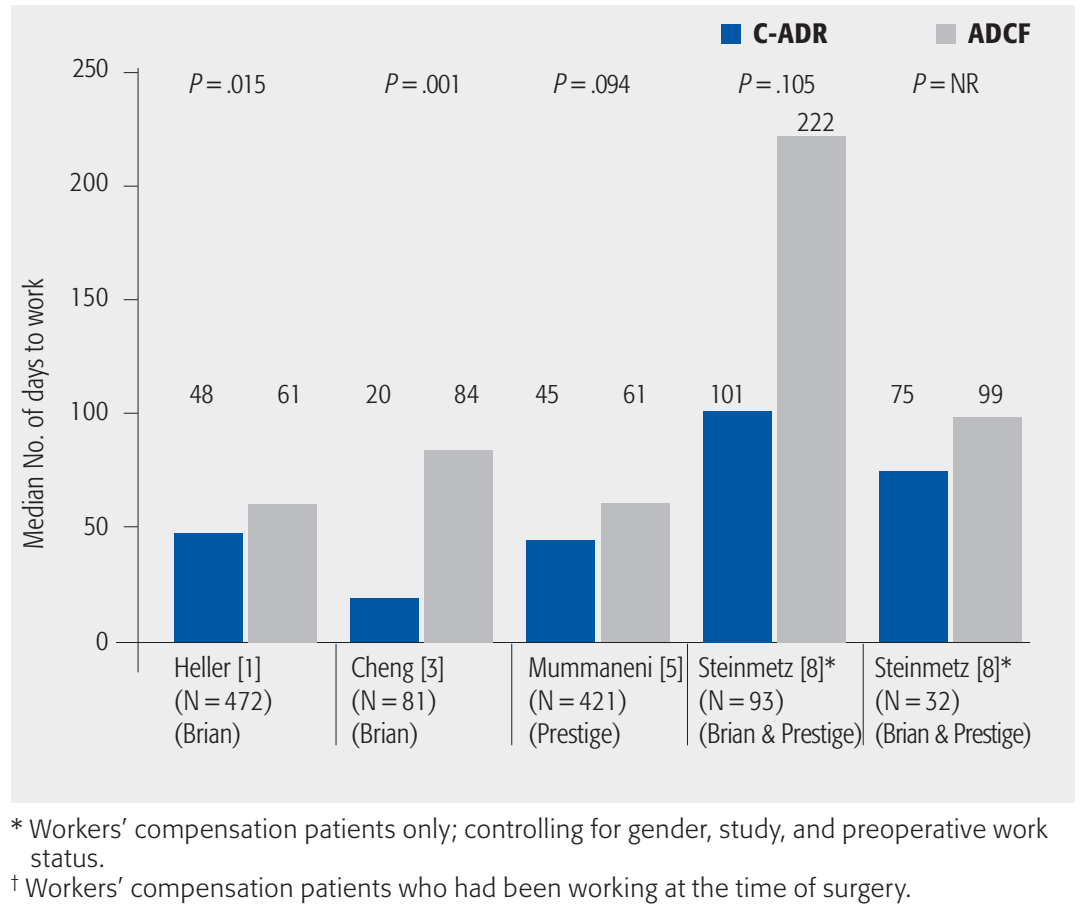




\section{CLINICAL GUIDELINES}

No clinical guidelines specific to the focus of this topic were found. General clinical guidelines related to C-ADR are summarized elsewhere in this issue.

\section{DISCUSSION}

This analysis of the data demonstrated that patients treated with disc replacement tended to return to work more quickly than those receiving fusion, but that overall return to work in the two groups was equivalent at 2 years. Both therapies have been shown to be safe and effective; therefore, it is expected that most patients will be able to resume normal productive lives.

The C-ADR patients tended to return to work sooner than fusion patients and the reasons for this are unclear. There are several potential explanations. The first is either patient or surgeon bias since neither group was blinded. At the time of enrollment for each of the studies, C-ADR had not been approved in the United States, and it could be presumed that the primary patient motivation to enter one of the studies was to obtain a C-ADR. This high level of interest could have led to a placebo effect in those receiving the C-ADR. Additionally, surgeons may have been more willing to release patients to work if they received a C-ADR. Finally, it may be that there is period during which the patient adjusts to the loss of a motion segment which is associated with increased discomfort, particularly with activity. Such an adjustment would not occur with $\mathrm{C}$-ADR and if real, could account for the difference in early return to work.

Conclusions from this review are limited by the following:

- Follow-up rates in the Prestige study were low; however, these low rates were due to the publication of articles before all patients had reached the follow-up window. Follow-up rates at 4 years were also fairly low $(75 \%)$ in the FDA Bryan trial; however, in both of these studies loss to follow-up was equivalent across treatment groups.

- Questions about return to work were assessed with patient self-report and apparently not validated with work records.

- No definition was provided of self-reported "return to work" (eg, how the question was asked, whether part-time work was included).

- The measures do not reflect return to work per se, as "return to work" assumes that patients were working before surgery. The proportions of people who are working do not reflect individual change from preoperative to postoperative, only group percentages at the various time points. These percentages were not

\section{EVIDENCE SUMMARY}

Table 3 Working and activity level.

\begin{tabular}{|c|c|c|c|c|c|}
\hline Outcomes & Strengt & dence & & & Conclusions/comments \\
\hline $\begin{array}{l}\text { Currently working } \\
\text { (short term) }\end{array}$ & Very low & Low & Moderate & High & $\begin{array}{l}\text { - Disc replacement patients were more likely than fusion patients to } \\
\text { be working at } 6 \text { weeks postoperatively in one study }\end{array}$ \\
\hline $\begin{array}{l}\text { Currently working } \\
\text { (long term) }\end{array}$ & Very low & Low & Moderate & High & $\begin{array}{l}\text { - No significant differences between treatment groups in proportion } \\
\text { of patients working after } 6 \text { months of follow-up in three RCTs }\end{array}$ \\
\hline Time to return to work & Very low & Low & Moderate & High & $\begin{array}{l}\text { - Earlier return to work following surgery for disc replacement than } \\
\text { for fusion across three RCTs; statistically significant differences } \\
\text { were seen in two studies }\end{array}$ \\
\hline Activity level & Very low & Low & Moderate & High & $\begin{array}{l}\text { - One study reported equivalent activity levels at } 24 \text { months in both } \\
\text { treatment groups }\end{array}$ \\
\hline
\end{tabular}


broken down by the work status of the patient before surgery, and included patients who were working postoperatively as well as those who were not working. Therefore, this measure does not accurately reflect return to work but rather work status at the time of follow-up in the study population.

- No direct comparison of patients with workers' compensation versus patients with other kinds of insurance was reported in a secondary analysis of the Bryan and Prestige trials. Workers' compensation patients comprised only about $10 \%$ of patients in those two trials, so that it is likely that the percentages reported in Table 2 for the full sample would be close to the percentages for the nonworkers' compensation sample. If that is the case, then indirect comparisons of the workers' compensation patients with the full sample would approximate differences between patients with and without workers' compensation.

- Only the published articles from the Bryan trial [1, 2] provided data on working status less than 2 years after surgery. Measures from earlier time points were collected in the Prestige trial and analyzed by Steinmetz et al [8], but they are not reported in the main articles from the Prestige study [4, 5].

\section{REFERENCES}

1. Heller JG, Sasso RC, Papadopoulos SM, et al (2009) Comparison of BRYAN cervical disc arthroplasty with anterior cervical decompression and fusion: clinical and radiographic results of a randomized, controlled, clinical trial. Spine (Phila Pa 1976); 34(2):101-107.

2. Sasso RC, Anderson PA, Riew KD, et al (2011) Results of cervical arthroplasty compared with anterior discectomy and fusion: four-year clinical outcomes in a prospective, randomized controlled trial. J Bone Joint Surg Am; 93(18):1684-1692.

3. Cheng L, Nie L, Li M, et al (2011) Superiority of the Bryan $\left.{ }^{\circledR}\right)$ disc prosthesis for cervical myelopathy: a randomized study with 3-year followup. Clin Orthop Relat Res; 469(12):34083414.

4. Burkus JK, Haid RW, Traynelis VC, et al (2010) Long-term clinical and radiographic outcomes of cervical disc replacement with the Prestige disc: results from a prospective randomized controlled clinical trial. J Neurosurg Spine; 13(3):308-318.

5. Mummaneni PV, Burkus JK, Haid RW, et al (2007) Clinical and radiographic analysis of cervical disc arthroplasty compared with allograft fusion: a randomized controlled clinical trial. J Neurosurg Spine; 6(3):198-209.

6. Murrey D, Janssen $\mathbf{M}$, Delamarter $\mathbf{R}$, et al (2009) Results of the prospective, randomized, controlled multicenter Food and Drug Administration investigational device exemption study of the ProDisc-C total disc replacement versus anterior discectomy and fusion for the treatment of 1-level symptomatic cervical disc disease. Spine J; 9(4):275-286.

7. Coric D, Cassis J, Carew JD, et al (2010) Prospective study of cervical arthroplasty in 98 patients involved in 1 of 3 separate investigational device exemption studies from a single investigational site with a minimum 2-year follow-up: clinical article. J Neurosurg Spine; 13(6):715-721.

8. Steinmetz MP, Patel R, Traynelis V, et al (2008) Cervical disc arthroplasty compared with fusion in a workers' compensation population. Neurosurgery; 63(4):741-747. 